UDK 338.001 .36

\author{
Kniazevych Anna, \\ D.Sc. in Economics, Associate Professor, The \\ Professor of the Department of Management, Rivne \\ State University of Humanities \\ ORCID 0000-0002-5394-5599 \\ kniazevich.a@gmail.com \\ Dmytruk Vitaliy, \\ Ph.D. in Philology, Associate Professor, The \\ Director, Separated Subdivision "Lviv Branch of the \\ Kyiv National University of Culture and Arts" \\ ORCID 0000-0002-4778-010X \\ wid_ua@ukr.net \\ Hrynokh Natalia, \\ Ph.D. in History, Associate Professor, The Deputy \\ Director of Educational Work, Separated Subdivision \\ "Lviv Branch of the Kyiv National University of \\ Culture and Arts" \\ ORCID 0000-0002-0949-0072 \\ kriter@ukr.net
}

\title{
THE SYNERGETICS AS A CONCEPT OF SOCIAL DEVELOPMENT
}

The purpose of the article is the investigation of the processes of the formation and establishment of the main provisions of synergetics, as of a modern concept of development, and of its practical application. The methodology. The synergetics paradigm is an interdisciplinary philosophical generalization, an explanation of various kinds of doctrines and approaches to the study and analysis of practically any phenomena in nature. The synergetic approach to reviewing the state of the management system is to see in the chaotic unstable (in terms of details) system future orderliness and stability, to simulate the course of certain social and economic processes and to provide a forecast using synergetic methods and chaos theory. Scientific Novelty. The results of the research provide the study and substantiation in the interdisciplinary aspect of the possibility of using the synergetic theory as a modern concept of development in various fields of scientific activity, including economics and management. Conclusions. Nonlinear processes cannot be precisely predicted, because development happens through the random choice of the path at the moment of bifurcation. With its help, one can study the laws that determine the nature of crisis phenomena in economics, management, politics, and society. Synergetics, as a universal approach to the disclosure of the nature and explanation of a wide range of various phenomena of reality, can be widely used for the analysis and modeling of managerial situations.

Key words: development, nonlinearity, chaos, dissipation, synergetics, bifurcation points, attractors, mechanisms of management of innovative development.

Князевич Анна Олександрівна, доктор економічних наук, доцент, профресор кафедри менеджменту Рівненського державного гуманітарного університету; Дмитрук Віталій Іванович, кандидат фрілологічних наук, доцент, директор Відокремленого підрозділу «Львівська фрілія Київського національного університету культури і мистецтв»; Гриньох Наталія Василівна, кандидат історичних наук, доцент, заступник директора з навчальної роботи Відокремленого підрозділу «Львівська фрілія Київського національного університету культури імистецтв»

Синергетика як концепція суспільного розвитку

Ціль статті - дослідження процесів формування і становлення основних положень синергетики як сучасної концепції самоорганізації та розвитку систем, а також її прикладного значення для суспільства. Методологія дослідження базується на синергетичній парадигмі як міждисциплінарному філософському узагальненні, поясненні різного роду учень і підходів до вивчення та аналізу практично будь-якого явища в природі. Синергетичний підхід до розгляду стану систем управління полягає в тому, щоб уникнути хаотичності, незручності з точки зору деталей системи, що впорядковуються і стабілізуються, і змоделювати перебіг певних загальноєвропейських процесів та зробити прогноз за допомогою методів синергетики і теорії хаосу. Наукова новизна. Результатами дослідження $є$ вивчення і обґрунтування в міждисциплінарному аспекті можливостей застосування синергетичної теорії як сучасної концепції розвитку різних галузей суспільної діяльності, зокрема в управлінні, економіці, соціокультурній сфрері. Висновки. Нелінійні процеси неможливо точно спрогнозувати, оскільки їх розвиток здійснюється через випадковість вибору шляху в момент біфуркації. За допомогою синергетики можна вивчити закономірності, які визначають природні кризи в економіці, управлінні, політиці, культурі. Синергетика, як універсальна методика підходу до розкриття сутності та пояснення широкого кола різних явищ дійсності, може широко використовуватися для аналізу та моделювання управлінських ситуацій в усіх сферах суспільного життя.

Ключові слова: суспільство, нелінійність, хаос, дисипація, синергетика, точки біфуркації, атрактори, механізми управління інноваційним розвитком.

Князевич Анна Александровна, доктор экономических наук, доцент, профрессор кафредры менеджмента Ровенского государственного гуманитарного университета; Дмитрук Виталий Иванович, кандидат фрилологических наук, доцент, директор Львовского филиала Киевского национального университета культуры и искусств; Грынёх Наталья Васильевна, кандидат исторических наук, доцент, заместитель директора по учебной части Львовского фрилиала Киевского национального университета культуры и искусств

Синергетика как концепция общественного развития

Цель статьи - исследование процессов формирования и становления основных положений синергетики как современной концепции самоорганизации и развития систем, а также ее прикладного значения для общества. Методология исследования базируется на синергетической парадигме как междисциплинарном философском обобщении, объяснении разного рода учений и подходов к изучению и анализу практически любых явлений в природе. Синергетический подход к рассмотрению состояния системы

(c) Kniazevych A., 2019

(C) Dmytruk V., 2019

(c) Hrynokh N., 2019 
управления состоит в том, чтобы увидеть в хаотической, неустойчивой с точки зрения деталей системе будущую упорядоченность и стабильность, смоделировать ход определенных общественных процессов и сделать прогноз с помощью методов синергетики и теории хаоса. Научная новизна. Результатами исследования является изучение и обоснование в междисциплинарном аспек те возможности применения синергетической теории как современной концепции развития в различных сферах общественной деятельности, в частности в управлении, экономике, социокультурной сфере. Выводы. Нелинейные процессы невозможно точно спрогнозировать, поскольку их развитие осуществляется через случайность выбора пути в момент бифуркации. С помощью синергетики можно изучать закономерности, которые определяют природу кризисных явлений в экономике, управлении, политике, культуре. Синергетика, как универсальная методика подхода к раскрытию сущности и объяснения широкого круга различных явлений действительности, может широко использоваться для анализа и моделирования управленческих ситуаций во всех сферах общественной жизни.

Ключевые слова: общество, нелинейность, хаос, диссипация, синергетика, точки бифуркации, аттракторы, механизмы управления инновационным развитием.

The relevance of the research topic. The synergetic paradigm, as an interdisciplinary philosophical generalization, an explanation of various kinds of doctrines and approaches to the study of virtually any phenomena in nature and society, is a universal method of cognition and has a philosophical and conceptual significance.

The term "synergetics" as the name of the new interdisciplinary research direction, was first introduced into the scientific circulation by the German professor of theoretical physics, Dr. G. Haken [21] during his lectures in the University of Stuttgart in 1969. In his worldview, H. Haken, as he thinks, is close to Aristotle. He is convinced of the existence of general laws that are relevant not only for the fundamental constituents of matter but also for the behavior of complex systems of any nature. Synergetics is the study of the interaction of elements within complex systems, as a result of which new macroscopic properties of these systems arise.

At the end of the $20^{\text {th }}$ beginning of the $21^{\text {st }}$ centuries, the division of science into separate directions and branches reached what was later called the bifurcation point. Such a situation is now observed in virtually all areas of science, in physics, mathematics, biology, chemistry, sociology, economics and management - there are dozens and even hundreds of scientific fields and specializations. At their intersections, so-called interdisciplinary sciences are constantly emerging. The scientific activity of modern times has been divided into small parts. Scientists, who are narrow specialists, conduct deep studies of their scientific fields and lose a coherent vision of the diversity of phenomena. At his time, Aristotle wrote his works on physics, and then he tried to generalize his observations and philosophically substantiate them in the work which he called "Metaphysics" that is "After Physics". It was a philosophical reflection and philosophical understanding of physics and his view of the universe.

A similar problem arose in the late $20^{\text {th }}$ - early $21^{\text {st }}$ centuries when there appeared the need for a philosophical generalization of a large number of separate sciences. There was the need for the emergence of a kind of "meta-science", which could summarize the results of separate disparate scientific activities and create a coherent worldview. This was supposed to be a philosophical generalized study of all discovered to that time laws of the surrounding world and nature.

Analysis of basic research and publications. Important contributions to the development and popularization of the synergetic theory are the scientific works by I. Dobronravova, Ye. Kniazeva, S. Kapitsa, S. Kurdiumov, H. Malynetskyi, I. Pryhozhyn, G. Haken and by many other scholars.

The study of the basic postulates of synergetic theory and of its use in various fields of science - philosophy, thermodynamics, management, economics, natural sciences, and other sciences is an urgent scientific and practical task. This problem was developed and continues to be studied by a number of scientists from different countries of the world and the results of this activity are reflected in modern scientific research of different directions.

The purpose of the article is the investigation of the processes of the formation and establishment of the main provisions of synergetics, as of a modern concept of development, and of its practical application.

Presentation of the original material. I. The basic provisions of the synergetic theory. The worldview significance of synergetics is difficult to be overestimated, as it creates the basis for developing a single scientific picture of the world, a single scientific worldview, based on a holistic representation of nature in its self-development. Unlike traditional branches of knowledge, Synergetics is interested in the general laws of the evolution of any system of nature. In the theory of self-organization, randomness plays a significant role. At bifurcation points, the system randomly chooses the path of evolution. In this way, the idea of the future changes. The future looks like a spectrum of predetermined attractors. "Chaos is not evil, but the "power", which creates structures - attractors of evolution, as well as the way to synchronize the pace of development of substructures in the middle of a complex structure" [6; 7]. Some scholars, for example, B. Rudyi [17], think that synergetics arose in response to the crisis of Darwin's traditional theory of evolution. He believes that the synergetic paradigm does not explain the origin of an extremely complex internal construction of the structural elements of the universe. ... If the organization is understood as the algorithmic structure, then matter never arranges itself without indicating the intelligence. "In this context, one of the most important ideological conclusions of the synergetic concept is the conclusion of the fundamental unity of the micro and microcosm" [2, 928].

Considering the graph of the development of a complex system to the point of bifurcation, we can see that this development is not a straight line, but a curve. That is, with the calm development in the space between the points of bifurcation the law of evolution takes effect. It acts very gradually, smoothly changing the development line. Thus, there is an alternation of the smooth, gradual development of the system with the spin-off, sharp changes at the moment of bifurcation. After the bifurcation point, the system gradually evolves adapting to new conditions. Thus, one cannot completely reject the evolutionary concept of development. It definitely takes place at certain times of development.

Synergetics, as the science of self-organization, seeks to discover the general rules of origin, the evolution of complex systems of any origin, their points of bifurcation, and the corresponding variants of attractors of future self- 
organization, that is, the fixed states to which the system comes after bifurcation.

In our fast time, we more than ever need non-standard, flexible thinking and the mobility of concepts that are capable of reflecting in the thinking of the mobility of phenomena in objective reality. The conservatism of thought and the propensity to outdated concepts are serious obstacles on the way of cognition. An example of this kind of non-standard thinking was the emergence of new synergetic concepts and methods of their use. Scientists in the most diverse areas of science and technology with amazement found out that synergetic concepts are confirmed in the analysis of phenomena in their specific types of scientific activity. Moreover, from another perspective, the synergetic technique allows looking at the history of society, philosophical understanding of the world and general laws, to which the existence and thinking of man are subject.

Thus, synergetics, as an interdisciplinary approach to the disclosure of the essence and explanation of a wide range of various phenomena of reality, gradually acquires features of the modern concept of development. The first attempts to use this concept in various areas of scientific research have already come to bear fruit. In information technologies, there are already synergetic computers that are able to distinguish between human faces. In the history of humankind, in its social and cultural development - it is the explanation of the role of randomness, spontaneity, and nonlinearity of human behavior. In biology, it is a new explanation of the processes of occurrence of development and extinction of biological populations. In neurophysiology - new approaches to the study of the activity of the human brain. In modeling, it is the passage of signals on the neural networks of the human nervous system. I. Dobronravova [3, 11] states that "synergetics as a general scientific research program is fundamentally transdisciplinary. It brings bridges between different scientific disciplines, without destroying their disciplinary certainty and without removing the specificity of those characteristics of self-organizing systems, which act as their control parameters and order parameters. The unity of methodological approaches is especially important when the subject of consideration is a person - the place of the intersection of all natural and humanitarian sciences. Namely, we have such a situation in education, when knowledge of brain processes and psychological settings of perception and understanding are equally important in the development of educational strategies. Now, the general scientific approach to these problems opens new possibilities for their solution." The synergetic worldview in the context of natural science is considered by many scholars as the one that causes paradigmatic transformations of the modern natural science tradition and is interpreted as the latest scientific revolution [2, 925]. Consequently, synergetics appeared as a new paradigm of human progress.

II. Management of the innovative development of enterprises on the basis of the theory of synergetics. The process of the establishment of an economic mechanism for managing the innovative development of enterprises can be conceptually considered with the help of the basic principles of the synergetic theory. Synergetics relies on the similarity of models, ignoring the nature of the systems, which they describe. The synergetic approach carries out the compression of information, and allows, avoiding details, describing and understanding of the properties and selforganization of such complex systems as economic problems of the development of the economic sectors. Synergetics can be used as a means of interpreting scientific data, and it allows evaluating factors, which may be left out of consideration in traditional analysis.

The formation of the economic mechanism is the process of development, management decisions and implementation of clearly defined goals, which will provide the most effective result on the basis of optimization.

According to the theory of management, optimization of solutions can be realized with the help of the scientific method, with the use of system orientation and application of models. The scientific method involves the development and testing of hypotheses. System orientation considers an organization as an open system consisting of interrelated parts. Modeling is a means of studying the process of forming an economic mechanism for managing innovation development. The development and adoption of rational decisions in the science of management mean that on the basis of system analysis, a mathematical model of the control object is created, after which the control algorithm, which is necessary for obtaining desirable characteristics of the process, is synthesized. Thus, the formation of the mechanisms for managing the innovative development of enterprise begins with system analysis, on the basis of which several variants of models are proposed and an algorithm for managing the investigated object is developed.

In researching innovative processes in such complex and multifactorial systems as enterprise management mechanisms, modeling is one of the practical methods for obtaining information about the behavior of the object of research under the influence of changes in operating factors. Let us consider the model as a simplified image of specific managerial situations, which, in many cases, allows clear generalized determining of the factors affecting the object, and their influence on the process of establishing control mechanisms. Modeling of management mechanisms, and of mathematical assessment of the degree of implementation of scientifically based constituents of the economic mechanism and instruments of organizational, legal, economic mechanisms and sociopsychological methods can provide objective information on the quality of management of enterprises and industries of the national economy. The obtained results of the analysis of the multifactorial reality with the use of the artificially limited number of variables of the model will be inaccurate. In addition, in practice, it is often necessary to solve problems related to the observation of random variables. For such problems, it is difficult to construct deterministic models; therefore, a fundamentally different probabilistic approach has to be used. The parameters of probabilistic models take into account distributions of random variables, their mean values, dispersions, etc. As a rule, these parameters are not known in advance, and statistical methods, previous experience and the construction of a decision tree are used for their estimation.

Analog and mathematical modeling can be used to simulate the activity of an enterprise. Analog models based on charts and diagrams are real objects of reality; however, they are not externally similar to them and can 
have a conceptual orientation, that is, to reflect the essence, the main operating factors of influence on a phenomenon, an event, its concept and directions of further development. Development of the concept and formation of management mechanisms is the process of integration of the main areas of activity, their diversification, analysis, and bringing multifactor phenomena to the logical chain of practical events that provide the highest economic and social effect.

The synergetic paradigm is an interdisciplinary philosophical generalization, an explanation of various kinds of doctrines and approaches to the study and analysis of practically any phenomena in nature. With its help, one can study the laws that determine the nature of crisis phenomena in economics, management, politics, and society. According to the theory of synergetics, one of the most important objective factors influencing the process of forming the mechanisms of management of innovative development of enterprises is the nonlinearity of economic transformations. In the broadest sense, the nonlinearity of the system lies in the fact that its response to the change of the external or internal environment is not proportional to the amount and volume of these changes.

An enterprise, as a multi-faceted and multi-factor social and economic entity, is a complex system that is subject to impact and load. The term "bifurcation" for social and economic systems can be considered as a factor in the external or internal environment, which radically changes equilibrium. The system stops following the given trajectory to the target and starts to deviate to another attractor. The term "bifurcation" can refer to the point of transition of the organization as a system from the mode of being attracted by one attractor (as the intended purpose of the activity) to the chaotically emerging attractors of bankruptcy and destruction. Bifurcations can lead the system beyond the boundary of stability, as a result of which, the organization enters the phase of chaos.

Synergetics, as a universal approach to the disclosure of the nature and explanation of a wide range of various phenomena of reality, can be widely used for the analysis and modeling of managerial situations. Attempts to use this concept in various areas of scientific research have proven to be effective [9, 332-334]. Enterprises and organizations, as social and economic systems, are complex and unstable; their evolutionary paths are constantly subject to various kinds of bifurcation influences. The desired result of the enterprise's activity can be achieved due to one or to a series of obscure, insignificant deviations in the trajectory of economic development. Each of these deviations only slightly changes the trajectory. However, after some time, the increase of small deviations (bifurcation) is sufficient for significant correction of the trajectory. The right choice of deviation allows for solving a task. The basic idea of controlling chaos is that the trajectory of the object changes, but the integrity of the system during this process remains.

Bifurcations in society are not necessarily due to the randomness or force majeure circumstances. Managers of enterprises, who understand the nature of the process in which they are assigned the role of making managerial decisions, face the task of timely interference and leading this process by installing artificially selected bifurcation points. They should direct the trajectory of the further development of the company in the right direction to the strategically planned attractor. At the same time, the company will create the necessary conditions for the use of synergy in the labor of the employees, will develop alternatives to the group behavior, will introduce appropriate innovations, and will create social and political movements that are effective and take into account the requirements and needs of the environment.

In the situation of adjusting the trajectory of the object under investigation, the deviation should not be too strong; the control must be extremely sensitive to the state of the system. It is important to establish how much freedom of action should be limited when the moments of instability are approached and, finally, the integrity of the system should not be ruined. Management tasks in the chaos are to try to maintain the stability of the system while simultaneously finding new alternatives for its further development. Innovative managerial decisions of enterprises should be aimed at stimulating the activity of new social forces, promising norms, and principles of management organization, and values that can provide further social and economic development of the society and branches of the national economy.

Scientific Novelty. The research and substantiation in the interdisciplinary aspect of the possibility of using the synergetic theory as a modern concept of development in various fields of scientific activity, including the process of formation and operation of the mechanisms of innovative development management of enterprises and sectors of the economy.

Conclusions. Synergetics is interdisciplinary field research, which is actively developing. With its help, one can study the laws that determine the nature of earthquakes, stock collapses, "explosive" social conflicts and other phenomena of human existence and reality.

The synergistic approach to reviewing the state of the management system is to see in the chaotic unstable (in terms of details) system future order and stability.

In the process of research, it is necessary to simulate the course of certain social and economic processes and in general, terms to give a forecast, using synergetic methods and chaos theory. Of course, these methods themselves do not guarantee a sharp transition of enterprises to the higher organizational and economic level of development, but they provide an opportunity to determine the general ways that can be realized with the discussion of the conditions and events, in which the desired self-organization can take place. A model for the further development of enterprises through a synergistic approach will help to describe what steps should be taken to change the existing state, and accelerate the development of events and lead it in the right direction.

To implement certain innovational changes, it is necessary to organize a number of bifurcation points at all levels of management. To change the organizational and economic condition of the enterprise, there are several ways for further development. Using scientifically grounded bifurcation barriers, it is necessary to direct development to the desired, pre-planned state - an attractor. If there is an algorithm for the access to a scientifically based 
attractor, then the time is saved and the material costs for its achievement are reduced. The algorithm for entering a level that would meet modern social and economic requirements begins with the formation and practical use of the established management mechanisms for innovation development.

\section{תimepamypa}

1.Бранский В.П. Теоретические основания социальной синергетики. Вопросы философрии. 2000. №4. С. 112-129.

2.Всемирная энциклопедия: Философия / Главн. науч. ред. и сост. А.А. Грицанов. Москва: АСТ, Минск: Харвест, Современный литератор, 2001. 1312 с.

3.Добронравова І.С. Філософія науки та синергетика освіти. Вища освіта Украӥни. 2003. №2(8). С. 7-12.

4.Євтодюк А.В. Освітні системи: синергетична інтерпретація еволюції. Вища освіта України. 2003. №2(8). С. 31-40.

5. Капица С.П., Курдюмов С.П., Малинецкий Г.Г. Синергетика и прогнозы будущего. Москва: Едиториал, 2003. 288 с.

6. Князева Е.Н., Курдюмов С.П. Законы эволюции и самоорганизации сложных систем. Москва: Наука, 1994. 236 с.

7.Князева Е.Н. Синергетический вызов культуре. Синергетическая парадигма: многообразие поисков и подходов. Москва, 2000. 69 с.

8.Князевич А.О. Ринок інновацій в складі інноваційної інфрраструктури країни. Маркетинг и менеджмент інновацій. № 3. 2015. C. $129-139$.

9.Князевич А.О. Управління інфраструктурним забезпеченням інноваційного розвитку економіки: моногр. Рівне: Волинські обереги, 2018. 362 с.

10. Kniazevych A., Kyrylenko V., Golovkova L. Innovation infrastructure of Ukraine: assessment of the effectiveness of the action and ways of improvement. Baltic Journal of Economic Studies. Vol. 4. No. 1 January. 2018. P. 208-218.

11. Кичкирук Т.В. Вища економічна освіта в концепції синергетичної парадигми нелінійного мислення. Anthropological Measurements of Philosophical Research. 2014. №5. C. 47-55.

12. Кремінь В.Г., Ільїн В.В. Філософрія: мислителі, ідеї, концепції: підруч. Київ: Книга, 2005. 528 с.

13. Малинецкий Г.Г. От мозга к компьютеру и обратно. Знание - сила. 1994. №9. С. 40-50.

14. Наконечна О.П. Естетичне як тип духовності: моногр. Рівне. 2002. 202с.

15. Остапчук О.Є. Можливості синергетики в розбудові інноваційного освітнього простору. Педагогіка та психологія. 2004. №4 (45). С.16-28.

16. Пригожин И. Философия нестабильности. Комментарий С.П. Курдюмова. Вопросы философии. 1991. № 6. С. 46-51.

17. Рудий Б. Криза еволюціонізму. Київ: Четверта хвиля, 2003. 116 с.

18. Синергетике 30 лет. Интервью с профессором Г.Хакеном. Проведено Е.Н. Князевой. Вопросы фрилософиии. 2002. № 3. C. $53-61$.

19. Тарасов Л.П. Самоорганізація матерії та дисипативні структури. Завуч. Наша вкладка. 2004. №36(222). С. 2-6.

20. Філософрія : підручник для вищої школи /за заг. ред. В.Г. Кременя, М. І. Горлача. Вид. 3-є, перероб. та доп. Харків: Прапор, 2004. 736 c.

21. Хакен Г. Информация и самоорганизация. Макроскопический подход к сложным явлениям [пер. с англ.]. 2-ое изд. Москва: КомКнига, 2005. 248 с.

\section{References}

1. Branskij, V.P. (2000). Theoretical grounds for social synergetics. Questions of philosophy. 4. 112-129. [in Russian]. Russian].

2. World Encyclopedia: Philosophy. (2001). Ed. by A.A. Gricanov. Moscow: AST, Minsk: Harvest, Sovremennyj literator. [in

3. Dobronravova I.S. (2003). Philosophy of science and synergetics of education. Higher education of Ukraine. 2(8). 7-12. [in Ukrainian].

4. Emelyanenko L. \& Shkoda T. (2016). Integration of science, education and production in synergetic paradigm of public management. MEST Journal, Belgrade, Serbia. 2. 64-76. [in English].

5. Kapica, S.P., Kurdjumov, S.P. \& Malineckij, G.G. (2003). Synergetics and forecasts of the future. Moscow: Editorial. [in Russian].

6. Knjazeva, E.N. \& Kurdjumov, S.P. (1994). Laws of evolution and self-organization of complex systems. Moscow: Nauka. [in Russian]. [in Russian]

7. Knjazeva, E.N. (2000). Synergy challenge to culture. Synergistic paradigm: a variety of searches and approaches. Moscow.

8. Kniazevych, A.O. (2015). Market of innovations in composition of the innovative infrastructure of country. Marketing and Management of Innovations. 3. 129 - 139. [in Ukrainian].

9. Kniazevych, A.O. (2018). Management of Infrastructure Provision of Innovative Economic Development. Rivne: Volyns'ki oberehy. [in Ukrainian].

10. Kniazevych, A., Kyrylenko, V. \& Golovkova, L. (2018). Innovation infrastructure of Ukraine: assessment of the effectiveness of the action and ways of improvement. Baltic Journal of Economic Studies. Vol. 4. No. 1. 208-218. [in English].

11. Kychkyruk, T.V. (2014). Higher economic education in concepts of synergetic paradigm nonlinear thinking. Anthropological Measurements of Philosophical Research. 5. 47-55. [in Ukrainian].

12. Kremin', V.H. \& Il'in, V.V. (2005). Philosophy: thinkers, ideas, concepts. Kyiv: Knyha. [in Ukrainian].

13. Malynetskyj, H.H. (1994). From brain to computer and back. Knowledge is power. 9. 40-50. [in Russian].

14. Nakonechna, O.P. (2002). Aesthetic as a type of spirituality. Rivne. [in Ukrainian].

15. Ostapchuk, O.Ye. (2004). Possibilities of synergetics in the development of innovative educational space. Pedagogy and Psychology. 4 (45). 16-28. [in Ukrainian].

16. Prigozhin, I. (1991). The philosophy of instability. Questions of philosophy. 6. 46-51. [in Russian].

17. Rudyj, B. (2003). The crisis of evolutionism. Kyiv: Chetverta khvylia. [in Ukrainian]. Russian].

18. Synergetics 30 years. Interview with Professor G. Haken. (2002). Questions of philosophy. By E.N. Knjazeva. 3. 53-61. [in

19. Tarasov, L.P. (2004). Self-organization of matter and dissipative structures. Zavuch. Nasha vkladka. 36(222). 2-6. [in Ukrainian].

20. Philosophy. (2004). Ed. by V.G. Kremen, M.I. Gorlach. Kharkiv: Prapor. [in Ukrainian]. [in Russian].

21. Haken, G. (2005). Information and self-organization. Macroscopic approach to complex phenomena. Moscow: KomKniga. 